\title{
Parasite abundance and its determinants in fishes from Brazil: an eco-epidemiological approach
}

\author{
Abundância parasitária e seus determinantes em peixes do Brasil: uma abordagem ecoepidemiológica \\ Cristina Fernandes do Amarante ${ }^{1 *}$; Wagner de Souza Tassinari ${ }^{2}$; Jose Luis Luque ${ }^{1,3}$; Maria Julia Salim Pereira ${ }^{1}$ \\ ${ }^{1}$ Programa de Pós-graduação em Ciências Veterinárias, Instituto de Veterinária, Universidade Federal Rural do Rio de Janeiro - \\ UFRRJ, Seropédica, RJ, Brasil \\ ${ }^{2}$ Departamento de Matemática, Instituto de Ciências Exatas, Universidade Federal Rural do Rio de Janeiro - UFRRJ, \\ Seropédica, RJ, Brasil \\ ${ }^{3}$ Departamento de Parasitologia Animal, Instituto de Veterinária, Universidade Federal Rural do Rio de Janeiro - UFRRJ, \\ Seropédica, RJ, Brasil
}

Received February 18, 2016

Accepted March 29, 2016

\begin{abstract}
The variability in parasite abundance has an ecological basis; however, from an epidemiological point of view, the contribution of factors inherent to the host to the variability in parasite abundance remains an open question. A database consisting of 3,746 specimens of 73 fish species was used to verify the relation between the distribution of parasite abundance in fishes and a set of biotic factors inherent to the hosts. Classical and mixed Poisson regression models were constructed. Prevalence ratios (PR) and their respective 95\% confidence intervals were estimated. The parasite abundance was significantly higher in female hosts, nonschooling species, species from benthopelagic and pelagic habitats, and fishes with greater body length. Overall, these results suggest that the variability in the abundance of infection is an attribute of the parasite species. Although the results are biologically plausible, important gaps may still exist and should be explored to better understand the variations in parasite abundance, which has great relevance in epidemiological studies. We reinforce the importance of choosing the statistical model most appropriate for the nature of the data to avoid spurious results, especially when the autocorrelation in the data is not taken into account.
\end{abstract}

Keywords: Epidemiology, parasite ecology, multivariate regression analysis, mixed model, fish parasite ecology.

\section{Resumo}

A variabilidade na abundância parasitária tem embasamento na perspectiva ecológica, entretanto, do ponto de vista epidemiológico, permanece em aberto a possibilidade da contribuiçáo de fatores inerentes aos hospedeiros para essa variabilidade. Foram analisados 3.746 espécimes, pertencentes a 73 espécies de peixes, para verificar a relação entre a distribuição da abundância parasitária em peixes e um conjunto de fatores bióticos inerentes aos hospedeiros. Modelos de Regressão de Poisson clássico e misto foram ajustados. As razóes de prevalência (RP) e seus respectivos intervalos, com 95\% de confiança, foram estimados. A abundância parasitária foi significativamente maior em hospedeiros fêmeas, não formadoras de cardumes, de hábitats bentopelágico e pelágico e com maior comprimento do corporal. De um modo geral, esses resultados sugerem que a abundância de infecção é um atributo da espécie de parasitos que pode ser variável. Apesar dos resultados apresentarem plausibilidade biológica, ainda pode haver lacunas importantes a serem exploradas para o melhor entendimento das variaçôes da abundância parasitária que, por sua vez, tem grande relevância nos estudos epidemiológicos. Reforça-se a importância da escolha de um modelo estatístico mais adequado à natureza dos dados, evitando-se resultados espúrios, principalmente quando não se leva em conta a autocorrelação entre os dados.

Palavras-chave: Epidemiologia, ecologia parasitária, análise de regressão multivariada, modelo misto, ecologia parasitária de peixe.

*Corresponding author: Cristina Fernandes do Amarante. Universidade

Federal Rural do Rio de Janeiro - UFRRJ, BR-465, Km 7, s/n,

CEP 23890-000, Seropédica, RJ, Brasil. e-mail: cristinaf.amarante@gmail.com. 


\section{Introduction}

Parasite abundance is defined as the number of individuals of a given parasite in a single host and can vary from zero to infinity (BUSH et al., 1997). The importance of detecting patterns that explain certain aspects of the host-parasite relationship, including environmental variables, has been recognized and remains a fundamental problem in parasitology, especially when aiming to explain the distribution of parasite abundance considering its epidemiological importance (VIGNON \& SASAL, 2010).

Typically, many hosts tend to harbor a few parasites, whereas a few hosts harbor many parasites, thus providing evidence of the aggregate abundance of parasites (AMARANTE et al., 2015; POULIN, 1993). From an ecological perspective, the variability in parasite abundance can be explained by the probability of the death of a parasite or by the emergence of a new infection in a given time interval, known as demographic randomness. Another relevant factor is environmental randomness, which involves the processes of the birth, death, migration and immigration rates that determine population growth and that depend on environmental factors (ANDERSON \& GORDON, 1982).

A question to be answered is whether other factors related to the biological characteristics and habits of the hosts can influence parasite abundance. Some studies on fish parasites conducted in Brazil tested the correlation between parasite abundance and host body length and sex (LUQUE et al., 1996, 2008; KNOFF et al., 1997); however, these studies were conducted with one or two host species and had inconsistent or few clear results.

Studies on the influence of the biological characteristics and the habits of hosts on parasite abundance are still challenging for researchers in the field. Among the tools available, statistical modeling techniques are very useful in trying to better explain the factors involved in determining an event of multifactorial nature. However, using a model adequate to the distribution of the data is of paramount importance to the validity of the analysis (KATZ, 2006a). In parasitology, some problems that hinder data analysis, such as aggregate distribution, can be overcome using mixed models (PATERSON \& LELLO, 2003). Mixed models, in addition to taking into account analyses among groups of very heterogeneous individuals, deal in an unbiased manner with some aggregation biases, better known as ecological fallacy (MEDRONHO et al., 2009). The erroneous assumption that attributes are homogeneously distributed among all individuals can be minimized using hierarchical levels consisting of groups to produce the desired internal homogeneity (GREENLAND \& ROBINS, 1994; MORGENSTERN, 1998). Thus, Vignon \& Sasal (2010) used modeling techniques based on classification and regression trees (CART) (BREIMAN et al., 1984; LOH \& VANICHSETAKUL, 1988) to seek answers to the variability of parasite abundance and found that the method provided a satisfactory outcome. However, these techniques do not take into account the different degrees of aggregation among species. Given this problem, the main objective of the present study was to evaluate and measure the relation between the distribution of parasite abundance and a set of biotic factors inherent to hosts in a sample of marine and freshwater fishes through the use and proposition of classical and mixed Poisson regression models.

\section{Materials and Methods}

\section{Data}

The present study used the database developed by Amarante et al. (2015), which consists of 3,746 fish specimens from 73 species, 54 marine and 19 freshwater, collected from 1991 to 2009 along the coast of the State of Rio de Janeiro $\left(21^{\circ}-23^{\circ} \mathrm{S}\right.$ and $\left.42^{\circ}-45^{\circ} \mathrm{W}\right)$

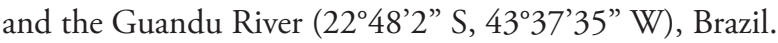

Briefly, the hosts and their parasites in the database were examined and identified at the Laboratory of Fish Parasitology, Department of Animal Parasitology, Federal Rural University of Rio de Janeiro (Universidade Federal Rural do Rio de Janeiro - UFRRJ) located on BR-465, Km 7, Seropédica, Rio de Janeiro state, Brazil. For analysis, Amarante et al. (2015) grouped the parasites found in the hosts into the following higher taxa: Nematoda, Monogenea, Trematoda, Cestoda, Acanthocephala, Hirudinea and Crustacea.

\section{Study variables}

The explanatory variables used in the present study were host sex (male/female), schooling habit (yes/no), aquatic environment (marine/freshwater), habitat (benthic/benthopelagic/pelagic), feeding habit (carnivore/planktivore/omnivore) and body length $(\mathrm{cm})$. Parasite abundance was considered the outcome variable.

\section{Statistical analysis}

Abundance was calculated for each host by the parasite taxon and independent of the taxon (BUSH et al., 1997).

To observe the pattern of abundance of the different parasite taxa, a univariate exploratory data analysis was performed to obtain the mean, median, variance, standard deviation and coefficient of variation. In addition, to better visualize the parasite abundance distribution among the different taxa, a boxplot was prepared on a logarithmic scale plus one. The Notch test was used to test statistical significance (CHAMBERS et al., 1983; MURREL, 2005). The Kruskal-Wallis test was used to compare the levels of parasite abundance among groups (KATZ, 2006b), which, in the present study, consisted of fish species.

The intraclass correlation coefficient (ICC) was calculated to assess whether the different fish species significantly contribute to the variability in the distribution of parasite abundance (DOHOO et al., 2003).

A bivariate analysis was performed, and a classical and a mixed Poisson regression model were subsequently constructed to allow a better understanding of the behavior of the study variables. The fish species were considered random effects in the mixed models. The prevalence ratios (PR) and their respective 95\% confidence intervals (CI) were calculated using the regression coefficients estimated by the models. As a modeling strategy, all variables were included in the models, thereby creating what is 
known as a full model. At each step, the nonsignificant variables were eliminated until the model that best explained the variability in parasite abundance was obtained. Model fit was evaluated using the Akaike information criterion (AIC).

All statistical analyses were performed in the $\mathrm{R}$ package, version 3.2.2 (R DEVELOPMENT CORE TEAM, 2014), using the software package MASS version 7.3-39 (RIPLEY et al., 2002) and nlme version 1.1-7 (BATES \& PINHEIRO, 2014).

\section{Results}

Table 1 shows that the parasite taxa with the highest mean abundances were Trematoda, followed by Nematoda and Cestoda, and that the highest variance was observed for the Trematoda, Cestoda and Nematoda. The Kruskal-Wallis test indicated that parasite abundance differed significantly among the fish species within each parasite taxon, as well as among fish species regardless of the parasite taxon. The absence of overlap in median abundances among the parasite taxa indicates that there was a significant difference in the variability of the parasite abundance among the taxa (Figure 1).
School formation, aquatic environment and planktivore feeding habits were not significant in the bivariate analysis (Table 2). The ICC calculation showed that $56 \%$ of the variability in parasite abundance is explained by the different fish species.

The behavior of all variables is observed in the full model (Table 3). In the classical model (Table 4), parasite abundance is significantly associated with all explanatory variables, which all behave as risk factors, except nonschooling and omnivore species. However, different results were observed in the final mixed model (Table 4), where only females, nonschooling species, pelagic and benthopelagic species and body length were associated with the variability in parasite abundance. All variables that remained in the final mixed model behaved as possible risk factors. According to the AIC, the fit of the mixed model (139602) was better than that of the classical model (230255).

\section{Discussion}

Parasite abundance as a quantitative parameter of parasite infections is considered to have a multifactorial nature and may vary as a function of the various biotic and abiotic factors (POULIN,

Table 1. Exploratory analysis of parasite abundance in marine and freshwater fishes from the State of Rio de Janeiro, Brazil.

\begin{tabular}{|c|c|c|c|c|c|}
\hline Parasite taxon & $\mathbf{N}$ & Mean & Median & SD & $\mathrm{CV}$ \\
\hline All & 168,677 & 45.03 & 12.00 & 182.52 & 405.33 \\
\hline Nematoda & 24,270 & 7.30 & 0.00 & 31.32 & 428.83 \\
\hline Monogenea & 14,715 & 4.97 & 0.00 & 16.30 & 327.83 \\
\hline Trematoda & 93,030 & 25.9 & 3.0 & 68.49 & 264.46 \\
\hline Acanthocephala & 1,804 & 0.88 & 0.00 & 3.69 & 416.63 \\
\hline Cestoda & 18,151 & 7.05 & 0.00 & 51.74 & 733.39 \\
\hline Hirudinea & 941 & 0.64 & 0.00 & 2.20 & 343.03 \\
\hline Crustacea & 15,766 & 5.43 & 0.00 & 23.40 & 431.01 \\
\hline
\end{tabular}

SD - standard deviation; CV - coefficient of variation.

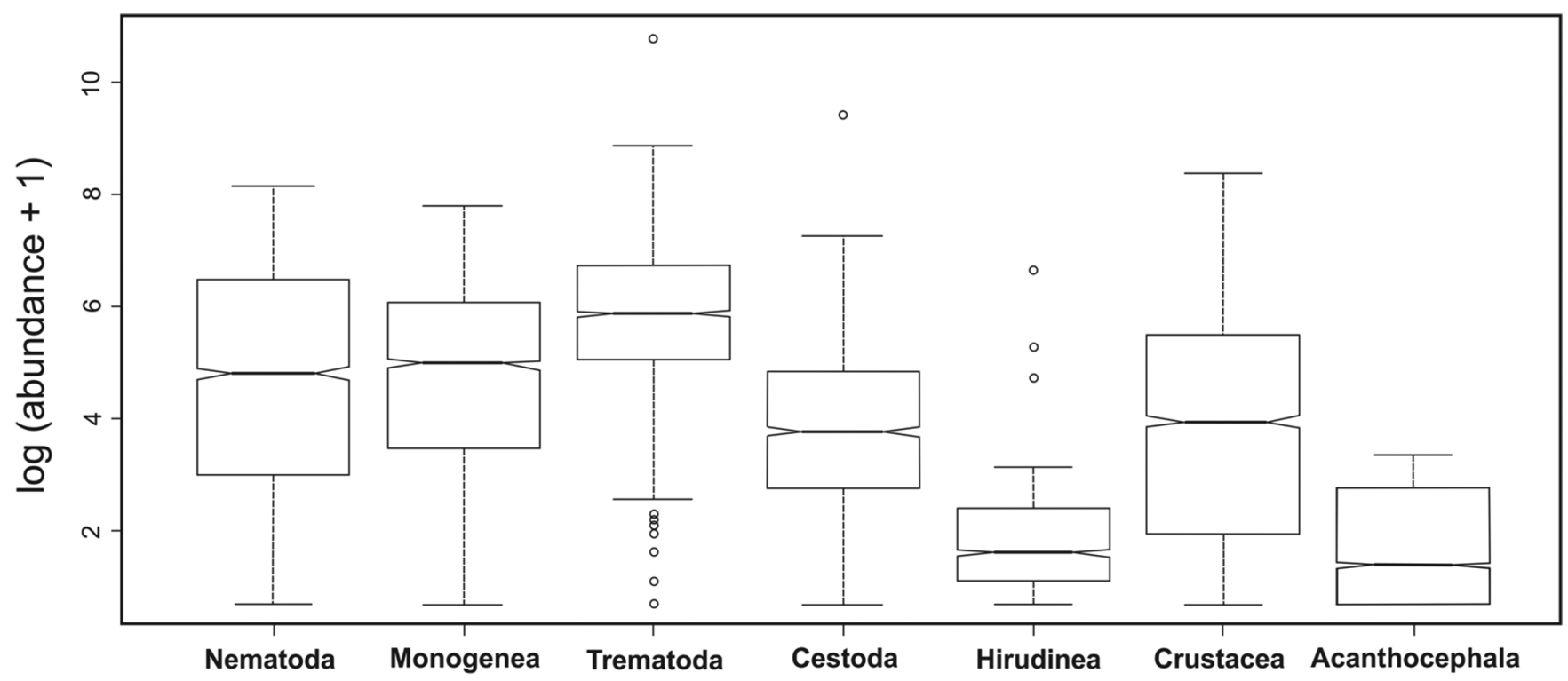

Figure 1. Distribution of parasite taxa in fishes from the State of Rio de Janeiro, Brazil. 
Table 2. Bivariate Poisson regression analysis for data of parasite abundance in marine and freshwater fishes from the State of Rio de Janeiro, Brazil.

\begin{tabular}{lcc}
\hline \multicolumn{1}{c}{ Variables } & Categories & $\begin{array}{c}\text { Prevalence ratio / } \\
(\mathbf{C I} \text { 95\%) }\end{array}$ \\
\hline Sex & male (ref) & {$[1.28(1.28,1.29)]$} \\
$\begin{array}{l}\text { Schooling } \\
\text { Aquatic } \\
\text { environment }\end{array}$ & yes (ref) & {$[1.73(0.97,3.10)]$} \\
Habitat & marine (ref) & {$[0.42(0.17,1.02)]$} \\
& benthic (ref) & \\
& benthopelagic & {$[1.99(1.16,3.41)]$} \\
Feeding habits & pelagic & {$[2.67(1.78,3.99)]$} \\
& carnivorous (ref) & {$[0.37(0.12,1.14)]$} \\
& planktivorous & {$[0.46(0.27,0.80)]$} \\
Body size & omnivorous & {$[1.02(1.02,1.03)]$} \\
\hline
\end{tabular}

CI - confidence interval; ref - reference category.

Table 3. Full, classic and mixed models of the multivariate Poisson regression for data of parasite abundance in marine and freshwater fishes from the State of Rio de Janeiro, Brazil.

\begin{tabular}{|c|c|c|c|}
\hline \multirow{2}{*}{$\begin{array}{l}\text { Variables/ } \\
\text { criterion for } \\
\text { model adjust }\end{array}$} & \multirow[b]{2}{*}{ Categories } & \multicolumn{2}{|c|}{ Prevalence ratio/ (CI 95\%) } \\
\hline & & Classic model & Mixed model \\
\hline Sex & male (ref) & $1.13(1.12,1.14)$ & $1.10(1.01,1.19)$ \\
\hline Schooling & yes (ref) & $0.66(0.65,0.67)$ & $1.60(1.02,2.51)$ \\
\hline $\begin{array}{l}\text { Aquatic } \\
\text { environment }\end{array}$ & marine (ref) & $1.29(1.26,1.31)$ & $0.69(0.40,1.19)$ \\
\hline \multirow[t]{3}{*}{ Habitat } & benthic (ref) & & \\
\hline & benthopelagic & $1.07(1.05,1.09)$ & $1.71(1.09,2.67)$ \\
\hline & pelagic & $1.62(1.59,1.65)$ & $2.40(1.60,3.58)$ \\
\hline \multirow[t]{3}{*}{ Feeding habits } & $\begin{array}{l}\text { carnivorous } \\
\text { (ref) }\end{array}$ & & \\
\hline & planktivorous & $1.36(1.32,1.39)$ & $0.58(0.20,1.68)$ \\
\hline & omnivorous & $0.82(0.81,0.84)$ & $0.98(0.56,1.71)$ \\
\hline Body size & & $1.04(1.04,1.04)$ & $1.02(1.01,1.02)$ \\
\hline AIC & & 235874 & 139607.2 \\
\hline
\end{tabular}

2007). As part of the characteristic of aggregation inherent to parasitism, abundance can be considered a highly variable species attribute, which is dependent on various characteristics intrinsic to the biology of the parasite and host and to the environment (ARNEBERG et al., 1998; PAMPOULIE et al., 2004; POULIN, 2006; HUTSON et al., 2011). The variability in parasite abundance is important from an ecological point of view, as a potential regulator of parasite populations and as a creator of interactive spatial structures (PEDERSEN \& FENTON, 2007; BELLAY et al., 2011, 2015), as well as from an epidemiological point of view, where the importance of parasite abundance in the spread of parasitic diseases is stressed (GALVANI, 2003).

The best way to study patterns related to parasite abundance is by considering this quantitative parameter in the context of several host biological characteristics; therefore, databases that include
Table 4. Final adjusted classic and mixed models of multivariate Poisson regression for data of parasite abundance in marine and freshwater fishes from the State of Rio de Janeiro, Brazil.

\begin{tabular}{|c|c|c|c|}
\hline \multirow{2}{*}{$\begin{array}{l}\text { Variables/ } \\
\text { criterion for } \\
\text { model adjust }\end{array}$} & \multirow{2}{*}{ Categories } & \multicolumn{2}{|c|}{ Prevalence ratio/ (CI 95\%) } \\
\hline & & Classic model & Mixed model \\
\hline Sex & male (ref) & $1.13(1.12,1.14)$ & $1.10(1.01,1.18)$ \\
\hline Schooling & yes (ref) & $0.66(0.65,0.67)$ & $1.64(1.03,2.62)$ \\
\hline $\begin{array}{l}\text { Aquatic envi- } \\
\text { ronment }\end{array}$ & marine (ref) & $1.29(1.26,1.31)$ & - \\
\hline \multirow[t]{3}{*}{ Habitat } & benthic (ref) & & \\
\hline & benthopelagic & $1.07(1.05,1.09)$ & $1.74(1.09,2.78)$ \\
\hline & pelagic & $1.62(1.59,1.65)$ & $2.39(1.61,3.54)$ \\
\hline \multirow[t]{3}{*}{ Feeding habits } & $\begin{array}{l}\text { carnivorous } \\
\text { (ref) }\end{array}$ & & \\
\hline & planktivorous & $1.36(1.32,1.39)$ & - \\
\hline & omnivorous & $0.82(0.81,0.84)$ & - \\
\hline Body size & & $1.04(1.04,1.04)$ & $1.02(1.01,1.02)$ \\
\hline AIC & & 230255 & 139602 \\
\hline
\end{tabular}

CI - Confidence interval; ref - reference category; AIC - Akaike information criterion.

hosts from the same locality to minimize geographical variations (LUQUE et al., 2010; TIMI et al., 2010; HUTSON et al., 2011; CANTATORE \& TIMI, 2015) are used to allow selection of a set of biotic characters common to the various species. The database used in the present study meets the requirements previously described, while simultaneously reducing the possibility of taxonomic problems related to the identification of parasites by the different groups of experts (AMARANTE et al., 2015).

Our results showed that the taxa Trematoda, Nematoda and Cestoda, which compose the main groups of fish endoparasites, had the highest abundance values. Most of these parasites have a life cycle that includes more than one host and infection via the trophic pathway, which increases the possibility of cumulative infections by adult parasites and larval stages. This enhances the size of their infrapopulations (sensu BUSH et al., 1997), especially for the larvae of the anisakid nematodes, acanthocephalans and cestodes that are characteristic of marine fishes commonly found along the coast of Rio de Janeiro (LUQUE \& POULIN, 2004).

The differences between the classical and mixed models indicate the need to test the possibility of data autocorrelation when the data structure suggests the existence of some correlation (DOHOO et al., 2003; KATZ, 2006a). In the present study, because several specimens of the same species were observed to form groups, the ICC, which was greater than $15 \%$, showed that the different fish species account for $56 \%$ of the variability in parasite abundance, indicating the need to use the mixed model (SNIJDERS \& BOSKER, 2012). In addition, the mixed model had a lower AIC than the classical model, justifying the selection of the mixed model as the most parsimonious.

The relation between the host body length (body mass) and parasite abundance has been reported in the literature (MUNOZ \& CRIBB, 2009; VIGNON \& SASAL, 2010) and is based on the increased resource availability to the parasites and the increased 
trophic volume in larger species, which ultimately means the acquisition of a greater number of intermediate hosts. Studies that investigated only one fish species have found heterogeneous results for the relationship between host size and parasite abundance (KNOFF et al., 1997; LUQUE et al., 1996, 2003, 2008; CHAVES \& LUQUE, 1999), which indicates a degree of inconsistency in this pattern that may be influenced by changes in the trophic habits of the host species studied (SAAD-FARES \& COMBES, 1992) and by abiotic factors that affect the presence or absence of parasite species (parasite diversity) and have been well documented by Luque et al. (2004). Although the current study and the study and Vignon \& Sasal (2010) used different approaches, both studies used multivariate analysis and confirmed the validity of this pattern in the evaluation of fishes from the same locality.

Significant differences in parasite abundance in female hosts may result from several factors, but the explanation for this finding is impaired by the lack of studies on the sex-related biology and behavior of the different host species studied. For example, differences in trophic habits, migrations, behavioral differences during the breeding season and population dynamics may directly impact abundance values. In contrast, immunological differences and other physiological aspects may alter the number of parasites in males and females (LUQUE et al., 1996; KNOFF et al., 1997). From this perspective, the finding of a significantly higher parasite abundance in nonschooling and pelagic and benthopelagic fishes was different from the expected (higher abundance in benthic and school-forming fishes). However, this may suggest a relevant degree of independence between parasite abundance and the behavioral biotic factors analyzed for possible association. Overall, these results suggest that infection abundance, in part, could be dependent of the biological characteristics of the host species, but also is a variable attribute of the parasite species, supporting the idea of Poulin (2006) that the biological characteristics of parasite species can potentially substitute local environmental conditions in parasite population dynamics.

The proper identification of determinants of parasite abundance requires a relatively large database, obtained directly from field collections, as well as the use of statistical techniques that consider the nature of the data (VIGNON \& SASAL, 2010). In addition to identifying the variables that can influence the parasite communities of fishes from Brazil, an important element of our study was the use of multivariate analysis techniques that allowed us to explore and assess the relative influence of the explanatory variables tested (categorical and continuous) on parasite abundance using a relatively large database. Although Vignon \& Sasal (2010) used multivariate techniques based on the hierarchy between the studied variables, their sample - marine fishes from two islands of the South Pacific Ocean - had totally different characteristics. In contrast, the comparison between the classical and mixed models performed in the present study sought to find the most parsimonious model, which was the mixed model, as it adequately addressed the correlated nature of the data.

The results of the present study, based on the confrontation of parasite abundance with host biotic factors, are ecologically plausible; however, they may have considerable consequences for the understanding of variability in parasite abundance, which is of great importance for epidemiological studies. This could be very useful to study some fish parasite populations, especially groups of zoonotic importance such as the anisakids, which cause anisakiasis, a parasitic disease that is a major public health problem in some European and Asian countries; anisakids are important components of the parasitic fauna of marine fishes from Brazil (PANTOJA et al., 2015). Due to the parasite distribution pattern observed among the studied taxa, stratified modeling should be used in future studies to examine the effect of association according to the specificity of each parasite taxon.

\section{Acknowledgements}

We acknowledge The National Council for Scientific and Technological Development (Conselho Nacional de Desenvolvimento Científico e Tecnológico - CNPq) for the financial support in the form of a doctoral scholarship to the first author and a research productivity grant to José Luis Luque.

\section{References}

Amarante CF, Tassinari WS, Luque JL, Pereira MJS. Factors associated with parasite aggregation levels in fishes from Brazil. Rev Bras Parasitol Vet 2015; 24(2): 174-182. http://dx.doi.org/10.1590/S1984-29612015031. PMid:26083693.

Anderson RM, Gordon DM. Processes influencing the distribution of parasite numbers within host populations with special emphasis on parasite-induced host mortalities. Parasitology 1982; 85(2): 373-398. http://dx.doi.org/10.1017/S0031182000055347. PMid:7145478.

Arneberg P, Skorping A, Read AF. Parasite abundance, body size, life histories, and the energetic equivalence rule. Am Nat 1998; 151(6): $497-$ 513. http://dx.doi.org/10.1086/286136. PMid:18811372.

Bates D, Pinheiro J. Linear mixed-effects models using Eigen and 44 [online]. CRAN; 2014 [cited 2015 Jul 15]. Available from: https://cran.r-project. org/web/packages/lme4/index.html

Bellay S, Lima DP, Takemoto RM, Luque JL. A host-endoparasite network of Neotropical marine fish: are there organizational patterns? Parasitology 2011; 138(14): 1945-1952. http://dx.doi.org/10.1017/ S0031182011001314. PMid:21854678.

Bellay S, Oliveira EF, Almeida-Neto M, Abdallah VD, Azevedo RK, Takemoto RM, et al. The patterns of organisation and structure of interactions in a fish-parasite network of a Neotropical river. Int J Parasitol 2015; 45(8): 549-557. http://dx.doi.org/10.1016/j.ijpara.2015.03.003. PMid:25900213.

Breiman L, Friedman JH, Olshen RA, Stone CJ. Classification and regression trees. Belmont: CRC; 1984.

Bush AO, Lafferty K, Lotz JM, Shostak AW. Parasitology meets ecology its own terms: Margolis et al. revisited. J Parasitol 1997; 83(4): 575-583. http://dx.doi.org/10.2307/3284227. PMid:9267395.

Cantatore DMP, Timi JT. Marine parasites as biological tags in South American Atlantic waters, current status and perspectives. Parasitology 2015; 142(1): 5-24. http://dx.doi.org/10.1017/S0031182013002138. PMid:24477070.

Chambers JM, Cleveland WS, Tukey PA, Kleiner B. Graphical methods for data analysis. Belmont: Wadsworth International; 1983. 
Chaves NN, Luque JL. Ecology of metazoans parasites of Menticirrhus americanus (Osteichthyes: Sciaenidae), coast are from Rio de Janeiro state, Brazil. Rev Bras Parasitol Vet 1999; 8(2): 137-144.

Dohoo I, Martin W, Stryhn H. Veterinary epidemiologic research. Charlottetown: University of Prince Edward Island; 2003.

Galvani AP. Epidemiology meets evolutionary Ecology. Trends Ecol Evol 2003; 18(3): 132-139. http://dx.doi.org/10.1016/S0169-5347(02)00050-2.

Greenland S, Robins J. Invited commentary: ecologic studies: biases, misconceptions, and counterexamples. Am J Epidemiol 1994; 139(8): 747-760. PMid:8178788.

Hutson KS, Brock EL, Steer MA. Spatial variation in parasite abundance: evidence of geographical population structuring in southern garfish Hyporhamphus melanochir. J Fish Biol 2011; 78(1): 166-182. http://dx.doi. org/10.1111/j.1095-8649.2010.02849.x. PMid:21235553.

Katz MH. Multivariable analysis: a pratical guide for clinicians. Cambridge: Cambridge University; 2006a.

Katz MH. Study design and statistical analysis. Cambridge: Cambridge University; 2006b.

Knoff M, Luque JL, Amato JFR. Community ecology of the metazoan parasites of grey mullets, Mugil platanus (Osteichthyes: Mugilidae) from the littoral of the State of Rio de Janeiro, Brazil. Rev Bras Biol 1997; 57(3): 441-454. PMid:9430918.

Loh WY, Vanichsetakul N. Tree-structured classification via generalized discriminant analysis. J Am Stat Assoc 1988; 83(403): 715-725. http:// dx.doi.org/10.1080/01621459.1988.10478652.

Luque JL, Alves DR, Ribeiro RS. Community ecology of the metazoan parasites of Banded Croaker, Paralonchurus brasiliensis (Osteichthyes: Sciaenidae), from the coastal zone of the State of Rio de Janeiro, Brazil. Acta Sci Biol Sci 2003; 25(2): 273-278. http://dx.doi.org/10.4025/ actascibiolsci.v25i2.2009.

Luque JL, Amato JFR, Takemoto RM. Comparative analysis of the communities of metazoan parasites of Orthopristis ruber and Haemulon steindachneri (Osteichthyes: Haemulidae) from the southeastern Brazilian litoral: I. structure and influence of the size and sex of hosts. Rev Bras Biol 1996; 56(2): 279-292.

Luque JL, Cordeiro AS, Oliva ME. Metazoan parasites as biological tags for stock discrimination of whitemouth croaker Micropogonias furnieri. J Fish Biol 2010; 76(3): 591-600. http://dx.doi.org/10.1111/j.10958649.2009.02515.x. PMid:20666899.

Luque JL, Felizardo NN, Tavares LER. Community ecology of the metazoan parasites of Namorado Sandperches, Pseudopercis numida Miranda-Ribeiro, 1903 and P. semifasciata Cuvier, 1829 (Perciformes: Pinguipedidae), from the coastal zone of the State of Rio de Janeiro, Brazil. Braz J Biol 2008; 68(2): 269-278. PMid:18660954.

Luque JL, Mouillot D, Poulin R. Parasite biodiversity and its determinants in coastal marine teleost fishes of Brazil. Parasitology 2004; 128(6): 671682. http://dx.doi.org/10.1017/S0031182004005050. PMid:15206470.

Luque JL, Poulin R. Use of fish as intermediate hosts by helminth parasites: a comparative analysis. Acta Parasitol 2004; 49(4): 353-361.

Medronho RA, Bloch KV, Luiz RR, Werneck GL. Epidemiologia. São Paulo: Atheneu; 2009.
Morgenstern H. Ecologic studies. In: Rothman KJ, Greenland S. Modern epidemiology. 2nd ed. Philadelphia: Lippincott-Raven; 1998. p. 459-480.

Muñoz G, Cribb TH. Parasite communities and diet of Coris batuensis (Pisces: Labridae) from Lizard Island, Great Barrier Reef. Mem Queensl Mus 2009; 52(1): 191-198.

Murrel P. Computer science and data analysis series. London: Chapman \& Hall; 2005.

Pampoulie C, Rosecchi E, Bouchereau JL, Crivelli AJ. Do environmental changes influence the occurrence and effect of parasites? J Negat Results Ecol Evol Biol 2004; 1(1): 8-15.

Pantoja CS, Borges JN, Santos CP, Luque JL. Molecular and Morphological Characterization of Anisakid Nematode Larvae from Sandperches Pseudopercis numida and Pinguipes brasilianus (Perciformes: Pinguipedidae) of Brazil. J Parasitol 2015; 101(4): 492-499. http://dx.doi.org/10.1645/14-625.1. PMid:25885554.

Paterson S, Lello J. Mixed models: getting the best use of parasitological data. Trends Parasitol 2003; 19(8): 370-375. http://dx.doi.org/10.1016/ S1471-4922(03)00149-1. PMid:12901939.

Pedersen AB, Fenton A. Emphasizing the ecology in parasite community ecology. Trends Ecol Evol 2007; 22(3): 133-139. http://dx.doi.org/10.1016/j. tree.2006.11.005. PMid:17137676.

Poulin R. Evolutionary ecology of parasites. Princeton: Princeton University Press; 2007.

Poulin R. The disparity between observed and uniform distributions: a new look at parasite aggregation. Int J Parasitol 1993; 23(7): 937-944. http://dx.doi.org/10.1016/0020-7519(93)90060-C. PMid:8106186.

Poulin R. Variation in infection parameters among populations within parasite species: Intrinsic properties versus local factors. Int J Parasitol 2006; 36(8): 877-885. http://dx.doi.org/10.1016/j.ijpara.2006.02.021. PMid:16620823.

R Development Core Team. $R$ : a language and environment for statistical computing [online]. R Foundation for Statistical Computing. 2014 [cited 2014 Jun 10]. Available from: http://www.R-project.org

Ripley B, Venables B, Bates DM, Hornik K, Gebhardt A, Firth D. Support functions and datasets for venables and Ripley's mass [online]. CRAN; 2002 [cited 2002 Jul 24]. Available from: https://cran.r-project.org/web/ packages/MASS/MASS.pdf

Saad-Fares A, Combes C. Abundance/host size relationship in a fish trematode community. J Helminthol 1992; 66(3): 187-192. http://dx.doi. org/10.1017/S0022149X00014541. PMid:1452993.

Snijders TAB, Bosker RJ. Multilevel Analysis: an introduction to basic and advanced multilevel modeling. London: Sage; 2012.

Timi JT, Lanfranchi AL, Luque JL. Similarity in parasite communities of the teleost fish Pinguipes brasilianus in the southwestern Atlantic: infracommunities as a tool to detect geographical patterns. Int J Parasitol 2010; 40(2): 243-254. http://dx.doi.org/10.1016/j.ijpara.2009.07.006. PMid:19682450.

Vignon MP, Sasal P. Multiscale determinants of parasite abundance: a quantitative hierarchical approach for coral reef fishes. Int J Parasitol 2010; 40(4): 443-451. http://dx.doi.org/10.1016/j.ijpara.2009.09.010. PMid:19861129. 